\title{
A Review of Distance Learning Influences on Adult Learners: Advantages and Disadvantages
}

\author{
Henry O'Lawrence \\ California State University Long Beach, Long Beach, CA, USA
}

holawren@csulb.edu

\begin{abstract}
This paper discussed the advantages and disadvantages of distance learning influences on adult learners. Distance learning has become popular in higher institutions because of its flexibility and availability to learners and teachers at anytime, regardless of geographic location. With so many definitions and phases of distance education, this paper only focuses on the delivery mode of distance education (the use of information technology), background, and its disadvantages and advantages for today's adult learners. Overall, distance learning is increasingly becoming an alternative in education, industry, large corporation, and various government entities, by and large when students, employees are far and wide spread geographically within and outside that region in which the course has been taken place.

As a result of this success, the benefits of distance learning have led many higher educational institutions to implement some distance learning classes, even if on an experimental basis. As a consequence, society in general may benefit from an overall increase in literacy through greater access to education (Belanger \& Jordan, 2004). In the United States alone, 62\% of public 4-year institutions offered some courses over the Internet in 1995, an increase of 150\% over 1992 (National Center for Educational Statistics, 1997).
\end{abstract}

\section{Introduction}

Distance Learning (DL) is defined as any type of instruction that takes place in which the student and instructor are not in the same room, and are separated by physical distance (Wahlstrom, Williams, \& Shea, 2003). It is one of the greatest advantages offered by modern electronic technology. Technology has the ability to instruct without the teacher's or student's direct presence in the classroom. With the growth of distance-learning programs, many institutions offer more on-line courses, and this has led to a growing interest in learning among adult learners and in continuing education (Verduin \& Clark, 1991).

Distance learning has become popular in higher institutions because of its flexibility and availability to learners and teachers at anytime, regardless of geographic location. With so many definitions and phases of distance education, this paper only focuses on the delivery mode of distance education (the use of information technology), background, and its disadvantages and advantages

Material published as part of these proceedings, either on-line or in print, is copyrighted by Informing Science. Permission to make digital or paper copy of part or all of these works for personal or classroom use is granted without fee provided that the copies are not made or distributed for profit or commercial advantage AND that copies 1) bear this notice in full and 2) give the full citation on the first page. It is permissible to abstract these works so long as credit is given. To copy in all other cases or to republish or to post on a server or to redistribute to lists requires specific permission from the publisher at Publisher@InformingScience.org for today's adult learners.

There were initial concerns that distance learning might lower the quality of instruction; however, studies show that its benefits are clear and demonstrable and it continues to gain acceptance. According to Belanger and Jordan (2004) several reasons play major 
roles in this growth; first, it opens up new opportunities for students who might otherwise be excluded from participation in the learning process. Second, it allows institutions to educate a larger number of students with relatively fewer instructors, thus providing a cost-effective method of delivering higher education. Third, learners have the opportunity to pursue lifelong learning after graduation regardless of lifestyle or location.

As a result of this success, the benefits of distance learning have led many higher educational institutions to implement some distance learning classes, even if on an experimental basis. As a consequence, society in general may benefit from an overall increase in literacy through greater access to education (Belanger \& Jordan, 2004). In the United States alone, 62\% of public 4-year institutions offered some courses over the Internet in 1995, an increase of 150\% over 1992 (National Center for Educational Statistics, 1997).

For commercial and governmental institutions, the focus is not as much on education as it is on training. Training is different from education in that it involves job-specific learning objectives and activities, and the content is specific to performance on the job. Corporations offer training to employees to ensure that they remain current with changes and innovations in their industry or field. Distance training provides these organizations with opportunities to let employees update their skills while remaining at their work place or their home. Distance learning offers companies the opportunity to maintain their employees' expertise as the company's business needs, as well as technology, rapidly evolve (Belanger \& Jordan, 2000).

Overall, distance learning is increasingly becoming an alternative in education, industry, large corporation, and various government entities, by and large when students, employees are far and wide spread geographically within and outside that region in which the course has been taken place.

According to Holmberg (1994), the growing need for adult training, the emphasis on lifelong learning, and the importance and value of distance teaching have become widely recognized. The number of nontraditional students has grown more rapidly than the number of traditional students (U.S. Department of Education, 2001). According to Chun and Hinton (2001), the growth of nontraditional adult enrollment in higher education demands a different and more flexible delivery system to meet students' needs. Distance learning is designed to ensure compatibility with the characteristics and needs of the adult learner, and by retaining their jobs while attending school, adult learners are able to continue to gain in work experience while pursuing educational goals (Nafukho, Thompson, \& Brooks, 2004).

Because of the rapid growth in distance learning, the use of technology has overcome many of barriers to higher education by providing traditional universities with an opportunity to meet the changing worldwide demand for education (National Committee of Enquiry into Higher Education, 2001). The demand for higher education is expanding throughout the world, and by 2025, as many as 150 million people will be seeking higher education (Goddard, 2000). Society requires higher levels of skills and qualifications to fill the same jobs (Davies, 1998), and individuals see education as a status provider (Pritchard \& Jones, 1996). This growth in demand will result in a transition in the type of students undertaking higher education, and the educational needs of individuals are becoming continuous throughout a working life as labor markets demand knowledge and skills that require regular updating (O’Neill, Singh, \& O'Donoghue, 2004).

According to Davies (1998), a phenomenon of lifelong learning has begun, and this new concept is quickly gaining social and political recognition as governments recognize the positive impact of education on the health and growth of modern economies. Consequently, higher education institutions will be required to provide for a more diverse student body, and, in particular, eLearning will provide for the significant growth in the mature student market. 
A recent report by the National Committee of Enquiry into Higher Education (2001) indicates that currently, more than $50 \%$ of higher education students are mature students (someone who starts a degree at age 21 or older). This figure is expected to increase as online learning and virtual universities allow educational experiences to be tailored to the needs of individuals or groups.

The online distance learning environment has a major contribution to make to the educational requirements of the $21^{\text {st }}$ century by encouraging general acceptance of the concept of knowledge as a vital element in social development and economic growth. Keeping pace with changes in technology and meeting the increasing demands of the knowledge-based economy will require a highly skilled and educated workforce capable of working collaboratively to find solutions to diverse economic, social, and environmental problems. The key to success is, in large part, continuing education, which means that online learning, with its open access and opportunities for active collaboration in an egalitarian environment, will have an important role to play in meeting the challenges of the future (Stansfield, McLellan, \& Connolly, 2004).

To make it convenient, distance learning courses take place on hybrid technologies, which combine various technologies for communicating via networks. According to Twiss and O'Lawrence (2002), hybrid courses are a blend of face-to-face instruction and online learning that satisfy students' need for convenient course offerings while making the best use of facilities, faculty resources, and online teaching technologies as the amount of classroom seat time is reduced. Even though traditional classroom methods continue to be important in learning, the use of technology helps to refocus how student needs are met.

\section{Background}

According to Belanger and Jordan (2004), distance learning is a type of education and training delivered to individuals who are geographically dispersed or separated by physical distance from the instructor, using computer and telecommunication facilities. Historically, the precursor of technology-based distance learning was correspondence education, which started in Europe and the United States in the mid $19^{\text {th }}$ century; it was established to provide education to those who could not attend traditional classroom environments, and used the postal system as a delivery mechanism. The most prominent of these delivery vehicles as we enter the new millennium is the Internet, which generated a new phenomenon of the virtual learning environment.

Sherron and Boettcher (1997) report that colleges and universities are implementing distance learning programs for three major reasons: the convergence of communication and computing technologies, the need for information-age workers to acquire new skills without interrupting their working lives for extended periods of time, and the need to reduce the cost of education. Most important, technology provides easy paths for connecting people with information, teaching, learning, and with other educational institutions (Gilbert, 1997).

Integrating information technology tools into teaching and managing classroom space is also becoming a critical issue as space fills and enrollment grows. This space/enrollment crunch brings particular focus on activities that integrate face-to-face and Web-based instructional formats, as well as instructional support in the use of system features. Educators are conjecturing whether the future success of online education will largely depend on professional collaboration and the sharing of resources, or whether technology will be fully integrated into higher education. Technology, along with the whole phenomenon of globalization, allows us to keep pace with change.

Many will argue that this type of technology has come to stay, and we should see technology as a requisite rather than a choice. If this is true, future college students will have to put up with technology-expert faculty, and faculty will have difficulty putting up with technology-ignorant students. Technology is changing rapidly and is providing new opportunities to rethink how we edu- 
cate students. However, new technologies mold into the old model of teaching and learning by enhancing lectures and increasing access to education for students located all over California. Recent data also indicated that the use of applications of information technology, in conjunction with teaching, is spreading faster than any other form of curricular change (Gilbert, 1997).

According to Burgstahler (2002), the multiple modes of delivery blur the lines between different types of distance learning such as television, course discussion using e-mail, a weekend retreat that brings participants together face to face, and/or resources provided on the World Wide Web. The multiple modes of delivery are definitely reshaping the world of higher education, revolutionizing teaching and learning practices and delivery systems. It has affected the social organization of teaching and learning in higher education by expanding the delivery of higher education and opening up opportunities to rethink the fundamentals of the higher education setting, such as the roles of students and teachers, time and place of instruction, and organizational participants (Gumport \& Chun, 2002).

These multiple methods can also facilitate teaching methods that build students' inquiry, problem-solving skills, and content knowledge in every subject. Multiple modes of delivery allow students to gain access to research sources via the Internet, work cooperatively in small groups using laptop computers, use multimedia tools to present what they have learned, and collaborate on projects with students around the world. It also helps accelerate changes in the teacher's role such as moving away gradually from a lecture mode of instruction to one in which instructors teach students to solve complex, real-world problems (NFIE, 2002).

According to Brown and Wack (1999), it is difficult to acquire clear, compelling evidence regarding the impact of technology on student learning outcomes. They also noted such studies attempting to provide this evidence are usually based on the assumption that such compelling evidence is attainable, and second, that even amid dizzying technological change and changing student populations such comparisons with conventional education are relevant. It is very important to specifically define or give in-dept clarification what is traditional or distance education means such as understanding what materials, motives, or methods are employed.

Let us not forget and as it is very important that we must not compared traditional institutions adopting part of their programs to be distance learning in form of hybrid or totally online but which their faculty are well educated with right qualification with other institution which mainly their objectives business and profit in mind generally. The authenticity of such program is very much questionable, along with the qualification of their faculty, in most cases such program has limited the quality of our educational system and college degree are becoming less valuable. A colleague of mine once mentioned in the faculty meeting that the way things are going anybody can have a college degree if they have the money. We are seeing people today that look good in the paper with all kinds of qualification, well impressed, but we cannot allow those people to become part of our traditional educational system. Those people are all about money not about good standard, good reputation, value and competitiveness spirit that would give our students an edge to be competitive in a global economy.

Moore and Kearsley (1996) stated that distance education means that students can have access to more and better learning resources than in the past. They wrote:

Rural and inner-city students can take courses previously available only to students in suburban areas. Handicapped and disabled students can have access to the same courses as everyone else - even if they are homebound or institutionalized. Adults who need specialized training for career enhancement or basic skills can take courses without having to be away from home or their current jobs. Students in one country can learn from teachers and fellow students in others. Courses can be accessed whenever the student wants, at 
whatever pace is preferred, from almost any location. Overall, distance education opens up many new learning opportunities for many people. (p. 15)

As Diaz (2000) indicated, many researchers endeavored for many years to determine whether distance education could provide the same level of academic excellence as courses taught in traditional modes; and much of the research from the 1980s and 1990s concluded that distance education was effective, "when effectiveness measured by the achievement of learning, by the attitudes of students and teachers, and by return on investment" (Moore \& Thompson, 1990, p. 59). A large portion of distance education research has been devoted to comparative studies of distance and traditional methods of education, and researchers conducting comparative research often ask the same basic research question: Is distance education as good as, or better than, traditional education?

According to Diaz (2000), this type of question is premised on the implicit yet rarely mentioned assumption that, traditional education is the ideal mode of educational delivery and thus can serve as the gold standard against which all other forms of alternative education should be measured. Diaz referred to the assumption as untenable simply because it is impossible to determine whether one class method is better than another without first agreeing on the criteria for such a determination.

\section{Distance Learning Issues}

Online technologies have opened up a new array of distance learning opportunities and, as a result, where once students had to drive a short distance or long distance to attend a class, computer-based systems allow those students to remain in their homes or workplaces to participate in learning activities. Students can attend class at a designated time; participate in an audio, video, or text-based chat; can post to bulletin board discussions; and can access information related to course work right from the computer (Heinich, Molenda, Russell, \& Smaldino, 2002).

It is important to identify and examine the main educational issues that were relevant to and influenced the development of the distance learning between students and teachers, as both have an important role to play. Students need to know their roles in distance learning and how to use the technology to communicate with the teacher and with each other. They not only need to know how to operate the microphone or how to post to a bulletin board discussion, but they also need to understand communication etiquette. The role of the teacher in an online learning environment is that they need to assume more responsibility for planning. The materials students will need must be prepared in advance while students must also understand what is expected of them in terms of their patterns of responses (Heinich et al., 2002).

The situation for online teachers appears at first sight to be a difficult one in that they cannot see or hear their students and cannot interact directly with them as in a face-to-face situation. Online learning is student centered and structured such that the course materials are presented in a suitable online format, with learning tasks, collaborative activities, and seminar and tutorial conferences being planned by the teacher but not teacher led and directed (Stansfield et al., 2004). It was argued that online teachers could not observe students, could not see and interpret their facial expressions or signs of inattention, and could not react immediately to rectify matters that may have gone amiss.

Certain features of online instruction are educationally advantageous, such as an increased opportunity offered for reflecting on and refining ideas, greater degree of learner control over the materials, flexibility permitted by unrestricted access to the materials, and enhanced levels of interaction both in relation to the materials and in the opportunities presented for active learning by means of conferencing, discussion groups, and collaborative learning projects (Stansfield et al., 2004). 
Isolation is another issue that has sparked a rigorous debate among researchers; the lack of interaction associated with eLearning is a prime concern in that electronic contact cannot sustain the qualities and multidimensionality of tutor-student relationships that real learning seems to require (Cooper, 1999). Bourner and Flowers (1997) further support this argument. They suggest that if technological developments are to be incorporated into higher education, they should be accompanied by increased human contact.

Moore (2000) claims that distance learners require a great deal of interaction mainly with the purpose of giving reassurance that everything is going well. The development of a virtual world motivates students to participate in the educational process by exploring and playing with the lesson materials. It can potentially provide an active, independent, student-centered and tutorfacilitated engagement, which enables communication with other students and tutors that may not always be available within the traditional classroom setting (O’Neill et al, 2004).

\section{Organizational Issues}

First, a decision must be made to determine how much of the course will be online. In other words, is this to be a Web-enhanced course or a Web-only course? The online component may range from occasional electronic assignments that supplement traditional class meetings, to a course that is online with two or three physical class meetings, to a course that is entirely online. Obviously many factors may be predetermined and out of the instructor's control; for example, if the course is intended for a geographically dispersed audience, then meeting face to face may not be an option (Lau, 2000).

Another organizational determination must be made as to the type of assignments and interactions that are to be included. These may range from group projects, created and delivered online, using process writing and interactions, or completely individual assignments. If everyone is moving through the course at the same time, could the interaction be enhanced by one or more synchronous activities, when all students are online simultaneously? As research has demonstrated, even in the case of having independent online lessons, it is useful to add a component that requires students to interact with their colleagues in some way (Dehler \& Poirras-Hernandez, 1998; Schrum, 1992). In addition, some mention must be made of the prerequisite skills that are expected of the students. Individuals who do not have experience with computers are found to be less able to learn from online courses since they spend enormous amounts of time completing the most basic of word processing tasks (Gibbs, 1998).

Although some educators prefer to determine their curriculum and activities as a course evolves, in this environment, it is especially important that students be given a list of readings, assignments, and expectations at the beginning of the course. The course must be well organized and introductory activities must be appropriate for novices and experts alike; collegial interaction must be fostered in some way. Rules for using any online environment need to be established among the group, for whichever configuration is ultimately chosen (Lau, 2000).

\section{Institutional Issues}

Institutional issues must be considered and discussed as an educational organization begins to focus on online education (Phelps, Wells, Ashworth, \& Hahn, 1991). Foremost must be recognition (perhaps in the promotion and tenure process) for faculty, but others might be by offering release time and assistance. Institutional support for innovative practices is essential, but it requires that time be allowed for design and development. While acceptance of this type of learning experience is growing, the reality is that at many organizations, online courses do not count as part of an instructor's teaching load and, further, the time necessary to prepare is not available 
prior to implementation. The resolution of these issues needs to be established before creation of any course (Lau, 2000).

Other institutional issues concern the amount and type of credit offered for online courses, and the students' ability to use the credit for postgraduate or graduate degrees, for salary increments, or certification. Will the students of a distance course be supported in registration, transcripts, etc., in the same ways as traditional on-campus students? Who will bear the expense of additional access and connections associated with online courses? Will modems or computers be loaned to students who cannot afford them? Will students be given access to the networks and other resources? How do students at a geographic distance gain access to materials on campus? Archiving resources online using the Internet can answer many of the access questions (Lau, 2000).

Last, it is essential that an evaluative component be included for every course. Is the course pedagogically sound? Has the course accomplished its educational goals? Is the organizational struc-

ture appropriate and equitable? Did the institution offer the support necessary for students and for the educator? Did unique problems arise from the nature of the online course or components?

Another issue concerns evaluation of the instructor. Currently students evaluate most instructors; however, in an online environment, the love of subject, commitment to students, sense of humor, and willingness to adapt might not come through. This calls for a more substantial and perhaps collaborative evaluation of the instructor by all stakeholders (Lau, 2000).

\section{Pedagogical Concerns}

Before decisions can be made about delivery or models, an instructor must make pedagogical decisions about the fundamental goals of a course. The salient questions when creating an educational experience have always been: "What are the instructional and personal goals of this course for all students?" "What is the purpose of this course?" These are questions that all educators must ask themselves when designing courses, and in general, they have become comfortable and adept at doing this (Lau, 2000). The structure of the course, the planning for educational and personal needs, and the teacher's role must all be reconceptualized. It is clear that active and independent learning must take place and the designer will have to determine what actions promote this type of learning.

The nature of online teaching requires the instructor to rethink the evaluation process as well. The evaluation component must be ongoing and continual; leaving everything to one midterm and a final paper would put everyone at a disadvantage. It is important that the instructor become familiar with each student's work, and the only way to accomplish that is through many instructional activities (Lau, 2000).

\section{Copyright Concerns}

The electronic delivery of instruction has created new concerns related to copyright law. For the most part, fair use applies. However, certain specific considerations have been recognized in distance learning:

1. Off-air recordings for nonprofit educational institutions are to be retained no more than 45 days.

2. Off-air recordings may not be altered from their original content. This included combining or merging, physically or electronically, to constitute teaching anthologies or compilations.

3. Broadcasting of copyrighted materials is allowed if the following terms are met:

a. The broadcast is part of a systematic, ongoing instructional activity. 
b. It is directly related and of material assistance to the teaching of content.

c. Transmission is received in classrooms only, or in similar settings normally devoted to instruction.

d. The broadcast is aimed at regularly enrolled students and conducted by a recognized educational institution. If the class is being recorded, it is a definite copyright infringement if prior approval for material presentation is not obtained. (Heinich et al., 2002, p. 301)

\section{Advantages of Distance Learning}

Many students take a distance-learning course with certain expectations about its advantages and its disadvantages. The following are identified as some of the advantages of a distance-learning course compared to a traditional classroom course:

- Flexibility: The greatest rationale for the existence of most forms of DL is that students can do much of the work at times and places of their choosing.

- Self-tailored learning: Within certain limits, distance learning may allow students to learn at their own pace, in their preferred medium, or in a more comfortable environment.

- More choices: Distance learning courses allow student more choices in course offerings and times without fear of class conflicts (Wahlstrom, Williams, \& Shea, 2003).

- Increased learner centeredness: Learners can study tutorials or add-on material at their own pace and at the appropriated time for them. This is particularly important for learners who suffer from not being able to follow the pace of the lectures, but who have the capabilities of catching up and finding the missing information by studying on their own.

- Instructors are able to combine lecture material with specific modules offering computer learning tools. This permits instructors to devote more time, if required, to covering concepts in class, while letting students learn the hands-on portion of the course on their own.

- For institutions, it reduces operational costs.

- Course standardization for courses in which there is a large number of potential learners; computer aided learning tools help achieve a certain level of standardization in the quality and quantity of material received by all learners.

- Lower course development costs. By centralizing the development of some of the learning tools, institutions may free up time for instructors to focus on other important teaching or training matters (Belanger \& Jordan, 2004).

\section{Disadvantages of Distance Learning}

It is also important to be aware that there are certain disadvantages to distance learning. The most significant disadvantage is that distance learning requires more self-discipline and time management. For some people, the expenditures required for computer equipment and Internet hookups outweighed the usual expenses of taking a conventional course such as commuting, parking, and perhaps babysitting (Wahlstrom et al., 2003). Some students feel lonely without face-to-face contact with other students, no matter how much they may communicate with others by phone or email; and Internet-based distance learning courses in particular rely on lectures as a means of in- 
struction and more on reading and discussion; thus, students who are uncomfortable with their reading and writing skills may find themselves equally uncomfortable with their distance learning course.

Heinich et al., (2002) indicated that, among other disadvantages, learners who participate in broadcast lessons without talkback capabilities can feel like second-class citizens having little rapport with the rest of the group. Technical problems may interrupt the instruction and may create confusion and frustration for the instructor and students. Also, because of inexperience, instructors may not feel comfortable teaching in this type of setting, and students may also be reluctant to assume greater responsibility for their own learning. Students may have difficulty making certain types of online connections as a result of their type of access to the Internet.

\section{Conclusion}

Many studies have attempted to find out whether distance education differs from traditional modes of instruction when referring to facilitating student success. The majority of these studies reported no significant differences between the distance and traditional modalities. Most important, the design of such type of research (whether comparative or evaluative) clearly places emphasis on the importance of the method of delivering instruction and is consistent with the instructivist (instructor-centered) learning theory but inconsistent with the constructivist (learnercentered) theory, which is more concerned with the role of the student in learning than with the role of the instructor in teaching (Diaz, 2000).

Teaching online courses could be very challenging, time consuming, and a lot of preparation is necessary to ensure that things are done well and students get feedback within 24 hours of posting their responses. It is certainly beneficial for instructors who have adopted online teaching to adopt Seven Principles of Effective Teaching Online: A Practical Lens for Evaluating Online Courses by Graham, Cagiltay, Lim, Craner, and Duffy (2001). The "Seven Principle for Good Practice in Undergraduate Education," originally published in the AAHE Bulletin (Checkering \& Gamson, 1987), proposes popular frameworks for evaluating teaching in traditional, face-to-face courses. The principles are:

1. Good practice encourages student-faculty contact. Lesson online instruction: Instructors should provide clear guidelines for interaction with students.

2. Good practice encourages cooperation among students. Lesson for online instruction: Well-designed discussion assignments facilitate meaningful cooperation among students.

3. Good practice encourages active learning. Lesson for online instruction: Students should present course projects.

4. Good practice gives prompts feedback. Lesson for online instruction: Instructors need to provide two types of feedback: information feedback and acknowledgment feedback.

5. Good practice emphasizes time on task. Lesson for online instruction: Online courses need deadlines.

6. Good practice communicates high expectations. Lesson for online instruction: Challenging tasks, sample cases, and praise for quality work communicate high expectations.

7. Good practice respects diverse talents and ways of learning. Lesson for online instruction: Allowing students to choose project topics incorporates diverse views into online courses. 
Finally, distance leaning is seen as a viable alternative for lifelong learning opportunities, including informal courses, professional development tutorials, and full degree programs. The growth of online courses, enhanced by the ease of access, media attention, and interest from the private sector, has increased demand, and efforts are underway to respond with various online learning activities (Lau, 2000).

Educators, course designers, and institutional planners must consider pedagogical policy and support issues before plunging into offering online courses. The community of scholars and educators must also create more avenues for sharing of experiences and research among all the international players by being willing to describe difficulties and take feedback from learners.

\section{References}

Belanger, F., \& Jordan, D. H. (2004). Evaluation and implementation of distance learning: Technologies, tools and techniques. Hershey, PA: Idea Group Publishing.

Brown, G., \& Wack, M. (1999). The difference frenzy and matching buckshot with buchshot. The Technology Source. Retrieved on November 27, 2004 from http://www.horizon.unc.edu

Bourner, T., \& Flowers, S. (1997). Teaching and learning methods in higher education: A glimpse of the future. Reflections on Higher Education, 9, 77-102.

Burgstahler, S. (2002). Distance learning: Universal design, universal access. Educational Technology Review, International Forum on Educational Technology Issues \& Applications, 10(1). Retrieved December 7, 2004 from http://www.aace.org/pubs/etr/issue2/burgstahler.cfm

Chun, H., \& Hinton, B. (2001). Factors affecting student completion in distance learning mediated HRD baccalaureate program. In O. A. Aliaga (Ed.), Proceedings of the Academy of Human Resource Development (pp. 85-992). Baton Rouge, LA: AHRD.

Chickering, A., \& Gamson, Z. (1987). Seven principles of good practice in undergraduate education. AAHE Bulletin, 39, 3-7.

Cooper, T. (1999). Whose academy is it? New Statesman, 128(4460), xxvi

Davies, D. (1998). The virtual university: A learning university. The Journal of Workforce Learning, 10(4), $175-213$.

Dehler, C., \& Poirras-Hernandez, L. H. (1998). Using computer medicated communication (CMC) to promote experiential learning in graduate studies. Educational Technology, 38(5), 52-55.

Diaz, D. P. (2000). Carving a new path for distance education research. The Technology Source. Retrieved on January 14, 2005 from http://ts.mivu.org

Gibbs, W. J. (1998). Implementing online learning environment. Journal of Computers in Higher Education, 10(1), 16-37.

Gilberti, A. F., \& Martin, G. E. (2002). Future technology teacher education programs based on standards for technological literacy. In Standards for Technological Literacy: The Role of Teachers Education, $51^{\text {st }}$ yearbook, Council on Technology Education (pp. 79-98). Glencoe-McGraw-Hill.

Gilbert, S. W. (1997). Re-focus on learning and teaching: Educational uses of information technology for everyone. The Technology Source. Retrieved on December 19, 2004 from http://ts.mivu.org

Goddard, A. (2000). Big brands key to e-university. Times Higher Education Supplement.

Graham, C., Cagiltay, K., Lim, B., Craner, J., \& Duffy, T. M. (2001). Seven principle of effective teaching: A practical lens for evaluating online courses. The Technology Source. Retrieved November 19, 2004 from http://ts.mivu.org

Gumport, P. J., \& Chun, M. (2002). Collaboration in distance education: From local to international perspective. In L. Foster, B. L. Bower, \& L. W Watson (Eds.), ASHE reader: Distance educationTeaching and learning in higher education (pp. 602-612). 
Heinich, R., Molenda, M., Russell, J. D., \& Smaldino, S. E. (2002). Instructional Media and Technologies for Learning $\left(7^{\text {th }}\right.$ Ed.). Upper Saddle River, $\mathrm{NJ}$ and Columbus, $\mathrm{OH}$ : Merrill Prentice Hall.

Henerson, M. E., Morris, L. L., \& Fitz-Gibbon, C. T. (1987). How to measure attitudes. Newbury Park, CA: Sage Publications.

Holmberg, B. (1994). Theory and practice of distance education. London: Routledge.

Lau, L. (2000). Distance learning technologies: Issues, trends and opportunities. Idea Group Publishing, Salomon Smith Barney, Inc. USA.

Moore, M. (2000). Is distance teaching more work or less? The American Journal of Distance Education, 14(3).

Moore, M. G., \& Kearsley, G. (1996). Distance education: A systems view. Wadsworth Publishing Company, USA.

Moore, M. G., \& Thompson, M. M. (1990). The effects of distance learning (Rev. ed. ACSDE Research Monograph No. 15). University Park, PA: American Center for the Study of Distance Education, Pennsylvania State University.

NFIE. (2002). Professional development and information technologies: Connecting the Bits. A reference for using technology in teaching and learning in K-12 schools. Retrieved July 3, 2002 from http://www.nfie.org

National Center for Educational Statistics. (1997, October). Retrieved on November 25, 2004 from http://nces.ed.gov

Nafukho, F. M., Thompson, D. E., \& Brooks, K. (2004). Factors predicting success in a distance learning nontraditional undergraduate degree program. International Journal of Vocational Education and Training, 12(2), 82-95.

National Committee of Enquiry into Higher Education. (2001). Report of the national committee. Retrieved November 25, 2004 from http://www.leads.ac.uk/educo1/ncihe/natrep.htm

O’Neill, K., Singh, G., \& O’Donoghue, K. (2004). Implementing eLearning programmes for higher education: A review of the literature. Journal of Information Technology Education, 3, 313-320.

Phelps, R. H., Wells, R. A., Ashworth, R. L., \& Hahn, H. A. (1991). Effectiveness and costs of distance education using computer-mediated communication. The American Journal of Distance Education, 5(3), 7-19.

Pritchard, A. L., \& Jones, D. R. (1996). Global learning. Open learning Australia. Retrieved November 25, $2004 \mathrm{from}$ http://www.intelecto.net/textos1/conferencias/s1_2.pdf

Schrum, L. (1992). Professional development in the information age: An online experience. Educational Technology, 32(12), 49-53.

Sherron, G. T., \& Boettcher, J. V. (1997). Distance learning: The shift to interactivity. CAUSE Professional paper Series, \# 17. Boulder, Colorado.

Stansfield, M., McLellan, E., \& Connolly, T. (2004). Enhancing student performance in online learning and traditional face-to-face class delivery. Journal of Information Technology Education. 3, 173-188.

Twiss, J., \& O'Lawrence, H. (2002). Information technology and occupational studies at California State University: Distance education. International Journal of Vocational Education and Training, 10(2), 93-104.

U.S. Department of Education (2001). Distance education at postsecondary education institution. Washington, DC: Author

Verduin, J. R., \& Clark, T. A. (1991). Distance education: The foundations of effective practice. San Francisco: Jossey-Bass Publishers.

Wahlstrom, C., Williams, B. K., \& Shea, P. (2003). The successful distance learning student. Belmont, CA: Scratchgravel Publishing Services, Wadsworth/Thomson Learning. 